\title{
Improvement for the Employability of College Students by the Second Class
}

\author{
Liu Ying \\ Chongqing three gorges university \\ College of Economics and Management \\ Chongqing, China \\ jsliuying@163.com
}

\author{
Yang Xiao-Hong* \\ Southwest University \\ College of Horticulture and Landscape Architecture \\ Chongqing, China \\ yangxh2@swu.edu.cn \\ *Corresponding author
}

\begin{abstract}
This paper analyzed the current employment status and the reasons for college students, described the second class produced by the combination of theory knowledge and practice activities, which had the character with theoretical basis and operation efficiency. Finally some countermeasures, how to use the second class in order to enhance the operational capability of students hands-on experience and observation, analysis, problemsolving abilities, comprehensively improve the quality and the employability of college students were suggested. From all above, college student employment rate will be markedly promoted more.
\end{abstract}

Keywords-component; the second class; teaching quality; employability; quality of jobs

\section{INTRODUCTION}

Economy is swift and violent development in an increasingly competitive world. Anxiously expect demand of public institution to university graduates also more and more highly, the high-level, high-caliber inter-disciplinary talent yue lai yue is regarded highly by society. Finding a decent job is becoming more and more difficult now. This year $6.99 \mathrm{~m}$ students will graduate from chinese universities, data from the human resources and social security ministry show. The news $6.99 \mathrm{~m}$ students need jobs makes 2013The history of the most difficult year of employment. Given the already grave employment situation in the country the employment pressure on university graduates will be obvious. How to improve their ability of employment upon graduation are many students most concerned about. Colleges and universities are important base to develop applied ability and creative ability of students. It is time to Break away from the single stereotype in the education and Cultivate applied innovative talents. With the development of social education, the second class as an extension of classroom education is extensively appreciated by the students. Through the second class, Can not only help students widen their horizons, extensive knowledge, grow in wisdom, and stimulate study interest, but also Help to consolidate what the students have learned and develop student's innovative spirit and practice ability.

\section{The Definition of "the SeCond Class"}

"The second class " refers to teaching activities related to "The first class "outside the teaching hours. Based on the teaching content, it comes from the textbook but not limited materials and it do not test, but also plays an important role in quality-oriented education. Based on the teaching form, it is lively and colorful. It's a very wide range of learning space: the classroom or the playground, the family or society [1]."The second class " is a comprehensive philosophy, Through the open attitude, changing education and teaching methods, and building the dynamic model of combining ideological education with the reality, we can purposely solve the problems of ideological and vocational education of college students in the new situation. "The second class" is a new dialogue. There is interaction between teaching and learning, teachers and students can participate in teaching and two-way communication [2].

\section{III. "The Second Class" Function and Advantages in IMPROVING THE EMPLOYABILITY OF COLLEGE STUDENTS.}

"The second class "and" The first class" are two effective ways of implementing the education; the main difference between them is that. The goal of "The second class " is to teach students basic knowledge, "The second class " has obvious advantages in promoting higher education, it can be mainly reflected from the following three aspects:

\section{A. "The second class" can improve the comprehensive quality and professional skill of students}

"The second class" will be based each student on their own characteristics to do the targeted teaching. It will combine their own interest and advantage to display their talent, get where they are and from innovation to the superior quality. Because "The second class" breaks the professional limitation and departmental boundaries, it is produced by the combination of theory and practice, with theoretical basis and operation efficiency. It can help students focus on the development of occupation technical ability and quality, cultivate students' occupation quality and improve their comprehensive ability.

\section{B. "The second class" is open}

Because of the flexibility of organization mechanism, independent mode, free and open, "The second class" breaks the traditional features of the "teacher-centered" teaching mold. The secret of "The second class" lies in the integration of 
theory with practice, Its allure defies time and place."The second class " not only can go out of the classroom, but also out of the school and society. It can achieve a reconciliation between theory and practice.

\section{C. "The second class" is good for the market competition ability of students}

"The second class " can promote the socialization and the degree of the market competition ability of college students: They can build interdisciplinary and interregional teams in practice, which can improve their communication and people skill. College students help each other and learn from each other in all kinds of activities, making them character and lively, cheerful, and do something practical, with good communication skills, teamwork spirit and collective sense of honor. These qualities are the demands of the society[1].

\section{THE DEFINITION OF EMPLOYABILITY}

Employability refers to ability needed in some kind of occupation, It includes the general and special employability. Zang Huili points out the general employment ability is divided into 5 categories of 16 technology:a)Basic skills: Reading, writing., learning ability: b) specialized skill : Professional knowledge, computer application skills, innovation ability; c)adaptability : Excellent problem solving, implementation capacity, self-control, anti-setback ability: d) Development ability : Honesty and hard work, responsibility, career planning; e) Communication ability: Interpersonal skills, coordinate ability, team work ability[3]. Special employability means special skills that special occupation needs, such as an accountant must have a good foundation in mathematics, the nurse needs some special nursing skills, art workers must have the sense of color, concentration, lines and image etc.

From a psychological point of view, employability is a comprehensive performance, There are several aspects: a) world view, outlook on life, value, attitude, habits ; b) interpersonal skills and cooperation with other departments; c)the capacity for self-management ; d)career planning capability; e)psychological adjustment[4].

\section{PRoblems IN THE ASPeCt of EMPloyability of THE College Graduate}

\section{A. Have no career map and career selected is improper}

Based on questionnaire survey in College of Economics and Management of Chongqing three gorges university graduates of 2013:60\% of the students occupational planning are quite vague at the time of graduation. They are not planning for their own occupation, their attitude is walking step by step. The survey found that $80 \%$ of the students were less likely to have sales employment. There are more than half students still choosing to stay in the mega cities. Their ideal occupation is teacher, institutions and civil servants, which exacerbates their employment.

\section{B. Lack of social experience}

The society and school are completely two different living environment. Recent college graduates have a hard time adapting to the changed world, because of the lack of social experience and the ignorance of avoiding some taboos.

\section{Indifferent interpersonal relationship}

With the rapid development of network technique, internet communication is becoming more common and important. Eighty percent college students have computer in chongqing three gorges university. Some contemporary graduated student's wallow in the network extricate oneself with difficulty. Those who indulge in the internet often feel isolated and being cut off from the outside world, gradually they tend to become introverted, withdrawn and unsociable.

\section{Have no good communication skills and team spirit}

Contemporary graduated student's are all single children. Their family is the focal point of their lives. Because they have no brothers or sister, they seem to care little about others, shut down communication and indulge in their own worlds. A recent study, by researchers at the university of michigan, found that college students today have significantly less empathy-the ability to understand and share the feelings of another-than students of generations past did. They have no good communication skills and team cooperation spirit.

\section{E. Poor ability to bear frustration}

Contemporary graduated student's are so self-important that he can't take a joke. They are looking for affirmation, direction, and hope, but at the same time, they're unwilling to accept criticism and admit mistakesBlame may lead to a strong reverse psychology. Most contemporary graduated student's comefrom good homes, and get a lot of attention. They don't have good mental quality and strong communication skills. It will have a huge psychological impact when they are in face of a series of blows.

\section{F. Lack of professional knowledge}

Knowledge and knowledge integration have been attached much more importance than ever by enterprises at the advent of knowledge-economy era. Contemporary graduated student's not only need social skills, but also with strong technical knowledge. Usually doesn't study hard, some students are poor at expertise and capabilities ${ }^{[5]}$.

\section{The WAY OF CARRYING OUT “THE SECOND Class”}

\section{A. Complete career planning}

College students career planning is very important for them to conquer employment difficulty and realize their ideals. Career planning includes four parts: first, as a freshman, adaptation and self-analysis; second, as a sophomore, initial analysis of occupation and orientation; third, as a junior, planning career life and fully preparing for 
it; fourth, as a senior, correctly choosing the career and realizing the goal. By improving the college students 'career planning capability, and cultivating their well-trained professional quality and career competence, the problem of college students' getting difficult finding jobs can be effectively solved.

\section{B. Evaluating themselves objectively}

For university graduates, it is always not so easy to find a good job. First of all, university students should make better preparation for employment, evaluating themselves objectively, improving their career outlook and adopting a correct attitude towards completion in employment. If it's a choice between higher pay and job security, they'd keep their job. Experience is more important for them.

\section{Be pre-professional}

University graduates can choose the career development channel according to their own characteristics, combine with business needs, and realize the career development planning with step up self integrated ability. Now many university graduates are pre-professional: they just want to be able to find decent jobs after graduation.

\section{Change the concept of employment conditions}

First, schools should do much in changing students 'employment concept and widening the channels for employment, which can create the good conditions for smoothing students' employment. Second, university graduates should change the concept of employment conditions is not necessarily a good place to go.

\section{E. Organize college students ' social practice}

To organize college students' social practice is an important means of carrying out quality education and improving students' knowledge and skills as well as their creativity and practical abilities, and promoting school reform. Information literacy of the college student accomplishment needs to be taken exercise and checked in social practice. Social practice can help university graduates able to self-supporting and adapt to the social life.

\section{F. Competence of interpersonal communication}

After they began to work, university graduates have to harmonize the relationship between the members or departments in the company. University graduates should be good at coordination and communication; These interpersonal skills training is particularly important. In "The second class", students learn to cooperate and compromise, and develop interpersonal skills needed for future success.

\section{G. Enhance team working ability}

Every year many universities will arrange some student activity according to the particular case, such as: various commemoration, learn-from-Lei Feng, all kinds of sports , competitions. Rich and colorful campus cultural life can create friendly atmosphere, making learning enjoyable Good organization ability and teamwork spirit and strong collective sense of honor. Through "the second class", university graduates could be good organization ability and teamwork spirit and strong collective sense of honor.

\section{H. Enforcing psychological counseling}

It is an imperious task for education teaching in colleges and universities to probe into the causes of learning frustration of the education participants and adopt the proper educational handling to improve their anti-setback ability. Maintaining a good attitude, shaking off professional sluggishness and enhancing the sense of self-value is very important.

\section{Develop expertise and capabilities}

Universities can invite relevant experts and scholars to do lectures according to the particular case. Development of scientific research in the university is a vital approach to enhance comprehensive faculties of university student and cultivate new talented person. Universities also can organize the professional competition to develop the students, expertise and capabilities. Clever design of $\mathrm{t}$ "the second class " activities are also beneficial to the students intellectual development, emotional development, to enhance student participation in awareness, sense of competition, to develop students the spirit of cooperation spirit and sense of innovation. The contemporary college students have not only professional theory knowledge and professional skill but also higher emotional quotient level.

\section{REFERENCES}

[1] Song-Hongsheng, Research on the Second Class Education of Colleges and Universities in Shanxi[J].Value Engineering,vol.16, pp. 253-254, 2011.

[2] Peng-Yangcheng,Wang-Yanqin,Ye-Xiaoqian,Zhang Xin,Research on the second class education[J].Legal system and society, pp. 233, April 2010.

[3] Zhang-Huili,Research on College Students' employment ability core[J]. Hubei Social Science,vol.10, pp. 177-178, 2009.

[4] Cai-Xiaokui, Research on Improving the employability of college students study and training practice teaching mode $[\mathrm{J}]$. Employment. Vol.3, pp. 35-37, 2013.

[5] Li-Dehai,Ji Gang,Qin Wei,Ability and quality contemporary university students should have [J]. Occupation space.Vol.6, pp. 71-72, 2010. 